J $\varnothing$ RGEN PODEMANN SøRENSEN

\title{
Ritualistics: a New Discipline in the History of Religions
}

What we are going to suggest on the following pages is not exactly a new method and still less a novel paradigm. And the new discipline to be outlined is not the science of ritual advocated by Frits Staal (1989) and not the cognitive, transformational approach of Lawson and McCauley (1990). It is in fact something much more traditional, and it will soon become apparent that ritualistics is a discipline to which many scholars have unwittingly contributed. The novel aim of the present paper is to define a discipline, i.e. an analytical level, analogous with the levels of analysis defined by such linguistic disciplines as phonetics, morphology, syntax and semantics.

The history of Religions is in need of subdisciplines. Those that it has are mostly derived from other academic disciplines such as psychology, sociology, or, to mention a more recent invention, aesthetics. Interdisciplinary studies are in many ways a characteristic, inherent feature of the humanities, and certainly not to be resented or mistrusted. It is, however, worth noticing that the History of Religions has only one discipline entirely of its own: a comparative, cross-cultural, religio-specific discipline sometimes called the phenomenology of religion. The phenomenology of religion spans everything religious and is to the study of a single religion what general, comparative linguistics is to the study of a single language. It consists in the construction of analytic models for use in the study of single religions. The phenomenology of religion has been variously viewed and evaluated, and the fluctuations of its self-esteem seem to reflect the general trends in the modern history of the humanities. Considered a concluding discipline that collects evidence towards asserting certain transhistorical universals, the phenomenology of religion is not easily reconciled with elementary standards of scholarship. It may as well, however, be viewed as an analytic tool discipline with the aim of constructing theoretical 
models, based on comparative analysis of historical data. In the latter case the objections seem to shrink to mere anti-theoretical routines.

If the idea of a comparative discipline in the history of religions is thus not in itself unsound, this does not solve all the problems that have been raised concerning the phenomenology of religion. There are still the endless discussions about its dependence on philosophical or Husserlian phenomenology, about the theoretical and even the religious basis of the works of van der Leeuw and Eliade, etc. etc. The present paper will not be contributing to the perpetuation of such discussions about individual approaches to the comparative project. The problem at issue is a much more fundamental one, inherent in the very idea of one broad comparative discipline in the history of religions. Even if we disregard the philosophical problem of a definition of religion, the idea of such an all-embracing discipline is not without its problems. Like the economists and anthropologists and many others, we are able to subsist without clearcut outer boundaries; but both practical and theoretical problems arise if we cannot inwardly structuralize our object. Many have probably seen the task of the phenomenology of religion as being an orderly construction of our object, and at least to some extent the traditional textbooks or treatises on the phenomenology of religion appear as lay-outs structuralizing the field of religion. It is, however, mainly a matter of chapter headings, and the lay-out differs so widely from book to book that one cannot perceive any consensus on essentials. Only van der Leeuw attempts a division into main levels: the object of religion, the subject of religion, and their interaction. But on the whole, what he does is to deal with a number of important and interesting themes, like everybody else. Comparative studies of interesting themes have been and will always be an important element in theory formation. But the task of constructing the object of a comparative discipline demands more conscious efforts.

Linguistics has succeeded in structuralizing its object into a number of clearly defined levels. It does not content itself with the study of themes, but operates a number of sub-disciplines, each defining a distinct level of analysis: phonetics, morphology, syntax, semantics - some of which may in turn be further subdivided. A theme may involve more than one of the levels defined by these disciplines, and the fact that linguistic analysis proceeds by accounting for the relations between such distinct levels is one of the main reasons for the admirable sophistication and the precise descriptions of the modern study of language. - Religion is probably as complex as language, and it is therefore appropriate that the comparative 
study of religion should not content itself with interesting themes, but also aim at distinguishing levels of analysis, thus dividing itself into subdisciplines. The present paper will only attempt a modest contribution towards this almost breathtaking project by identifying one such level: that of ritual.

\section{The Level of Ritual}

The study of ritual is more than just the study of a very broad theme. On the following pages we shall attempt to define the field of ritual as a distinct level, not immediately compatible with levels of belief, religious ideas, myth, etc. As a first argument in favour of our enterprise, let us cite a classical fallacy: A traveller repeatedly observes that the natives perform certain acts alleged to repel or overthrow evil spirits; generalizing slightly, he reports: "The fear of evil spirits prevails throughout Remotia." Today, such statements survive only in missiological textbooks, but it is not without interest to focus on the nature of the erroneous inference behind them. The obvious error is generated by a leap from one level to another: From the premises on the level of ritual, conclusions are immediately drawn on the level of beliefs, attitudes, motivations - wherever "fear of evil spirits" belongs. The traveller in Remotia ought to have investigated the ritual context of the repelling of evil spirits, i.e. to have accomplished his analysis on the level of ritual, before going on to infer anything on the level of general horror. The natives might retaliate by stating the fondness for biscuits throughout Christian Europe.

The distinctness and the peculiarities of the level of ritual have been observed by many, but the matter has never been carried to its full and general conclusion. There are not a few well documented cases, in which characteristic distinctive features of ritual vis-à-vis beliefs, myths, attitudes have been pointed out or nearly pointed out. We shall briefly deal with four such cases.

In one of his studies on the Lepchas of Sikkim, Halfdan Siiger (1978: 128) emphasizes the importance of ritual texts and the way they contribute to the picture of the great deities ( $r u m$ ) of the Lepchas, notably Kongchen, the protector and tutelary god of the country, and the primeval mother of mankind Nazongnyo. While the myths describe their tutelary and life-giving roles, a number of ritual prayers explicitly allow for the possibility that they might cause illness, death, and disaster among men. 
Thus, in a ritual for the new-born child (Siiger 1967/1: 122-125; Siiger 1967/2: text no. 18) Nazongnyo is asked not to bring sickness and death to the child:
"Maker of birth!
Maker of newcomer!
Who lets the birth come,
who lets the newcomer come.
Make the life good!
Make peace!
We have given butter pats,
we have given cí offering,
we have given rice offering..."

To [the child's name implied] do not cause death and sickness to occur!

A similar negative potential is a salient feature of the Great Kongchen Ceremony (Siiger 1967/1: 190-201; Siiger 1967/2: text no. 33-39), in which Kongchen is asked not to cause illness and disaster for the people or for the Maharajah. A prayer with two parallel invocations of Kongchen and his wife Cya dung ra zo, recited before and after the central rite of sacrifice, may serve as illustration:

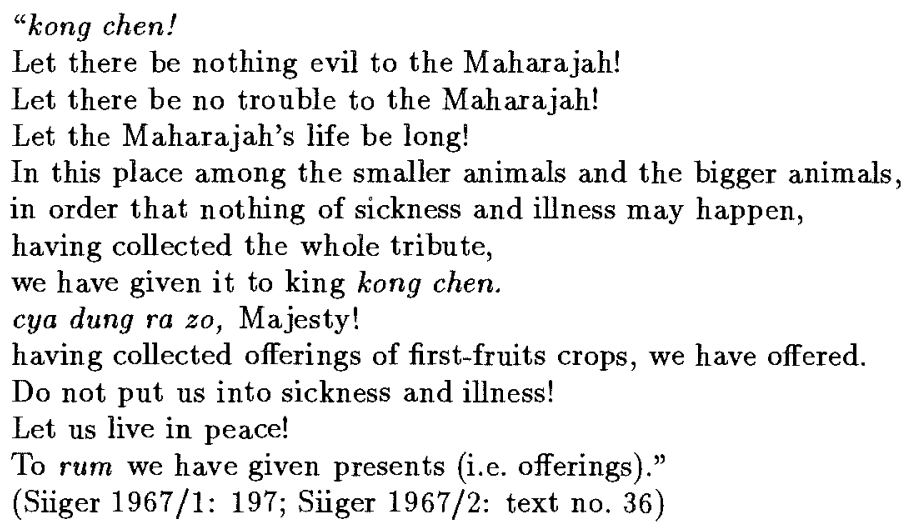

Closer inspection of the ritual context of the negative potential of Lepcha deities (rum) reveals the ritual determinants of this deviation from their mythical appearance. During the rituals both rum and mung ("demons") are represented as present, and the ritual for the new-born child as well as the ceremony of Kongchen conclude with a dismissal of the supernatural beings. In both rituals, dominating thernes - visible in the above quotations - are on the one hand potential illness and disaster, on the other hand the assertion that appropriate offerings have been given. Illness, death and disaster may be caused by mung, by warlike 
neighbours, but potentially also by rum like Nazongnyo and Kongchen. The whole disastrous potential is brought out during a ritual period, in which the supernatural beings are imagined as being present. In the Great Ceremony of Kongchen a ritual process may be followed through the ritual texts: there is a period of sacralization (texts no. 33-34), a liminal period (texts no. 35-36), and a period of desacralization (texts no. 37/38-39). The introductory text, which defines the yak to be sacrificed as the object of the ritual, already invokes Kongchen and asks him not to cause illness; but above all the disastrous potential indicates the liminal period, the critical turning point at which everything may happen. It is in the face of the same crisis that our texts emphasize ritual control. The ritually provoked and ritually controlled crisis is what makes a new beginning possible. The disastrous potential should thus be seen as elements in the ritual representation of this crisis, as means in the ritual process.

We may observe, then, that while a purely ritualistic analysis yields a consistent result, a theme like 'the idea of god' reveals two incompatible and contradictory levels or dimensions. At this point it will be useful to consider our second example, from Tord Olsson's (1983) remarkable study of the idea or image of god among the Maasai. The international debate on high-gods has repeatedly taken an interest in the sole god of the Maasai, enkAi, and his somewhat varied representation in Maasai tradition has contributed to theories of the historical development of highgods. On the basis of a comprehensive body of texts (Olsson 1975-1982) Tord Olsson has shown, however, that the varieties in the representation of enkAi are distributed on the main genres of religious texts and on certain religious speech situations with great regularity: In the myths, the anthropomorphic image of god is a formal feature of the narrative approach; but this is not taken literally in the sense that the Maasai narrators and their audience cherish an anthropomorphic idea of god. In hymns and prayers to enkAi, shifting manifestations of the god are regular; he may be identified with the sky, the earth, and other parts of nature, but in the supplications proper, i.e. in the speech situation of entreaty, he assumes anthropomorphic traits.

In Maasai tradition, literary genre and speech situation are thus determinants of the image of god, and quite in accordance with what we found among the Lepchas, the decisive dividing line runs between mythical and ritual texts. The discrepancies between the mythical and the ritual image of god are not clues to a historical development; they are contemporary dimensions of an image of god. We are dealing with two different and not directly compatible levels, the mythical and the ritual, not with 
diachronical layers of tradition.

This seems to favour our suggestion that in describing religion one should operate distinct levels of analysis. If ritual, myth, ideas, attitudes, etc. are huddled up at one level as equal constituents of "religion", the result is not likely to be a consistent and precise description. In many cases the failure to distinguish analytical levels has been the starting point for historical interpretations aiming at diachronical consistency at the cost of any coherent synchronous description. - Our third case, the centennial discussion on monotheist tendencies in ancient Egyptian religion, is a rather nice example: Since the latter half of the former century lectures, monographs and essays on ancient Egyptian religion have spoken of monotheist tendencies, of developments from an original monotheism into polytheism or developments towards monotheism. Original or final, Egyptian monotheism has its empirical basis in quite a number of religious texts from widely different periods which speak about the sun-god and sometimes also other gods as the one or the sole god. On the other hand the case for monotheism in ancient Egypt is somewhat impeded by the hundreds of gods referred to in texts at all periods in ancient Egyptian history - except the 17 years of Akhenaton's reign. Facing both the apparent ambiguity of the evidence and competing historical constructions, Siegfried Morenz (1960: $145 \mathrm{ff}$.) pointed out that a tension between the unity and the multiplicity of the divine was a central and inherent characteristic of Egyptian religion. Thus achieving a synchronous approach, Morenz was still operating a one-level theory of "Egyptian religion", and he saw systematizing attempts within the Egyptian pantheon (divine families, triads, etc.) as mediating the basic tension between the unity and the multiplicity of the divine.

On the achievements of Morenz, Erik Hornung (1971) could base a broader and more systematic investigation of Egyptian conceptions of god: Der Eine und die Vielen, one of the most seminal books in the modern study of ancient Egyptian religion. Still, at least at the outset, operating a one-level theory like Morenz, Hornung saw the mutually incompatible expressions and representations of the unity and the multiplicity of the divine as complementary statements towards the total Egyptian conception of god. It was a closer inspection of the ontological dimensions of unity and multiplicity that took him further: the world of the Egyptian consists of 'that which is' $(n t t)$ and 'that which is not' (jwtt). Non-being is potential being, the not yet manifest and differentiated existence, the primeval unity. Being, on the other hand, is always ordered and differentiated; coming into being means being singled out from this primeval unity, and 
creation means, above all, a process of differentiation. Behind the varied Egyptian mythologies of creation is the idea of the primeval One, "who makes himself into millions", and primeval time as the time when "no two things had yet occurred", i.e. as a state of undifferentiated unity. The mythical images are the limitless and unfathomable primeval ocean, the in discernible primeval darkness, and the sole creator god "with none beside him". The created world, the world of being with its rich differentiation, is but a tiny portion singled out from this immense universe of non-being; and to cease being is only to sink back into the inert, dark, and limitless state of pre-existence.

Non-being could be something frightening, the destruction of life or the world as the Egyptian knew it, or the deserts and wildernesses surrounding his beloved land. But it was also the source of being, as unity was the source of multiplicity. When divinity comes into being, it multiplies; absolute, exclusive unity is the prerogative of non-being. The henotheism we find in hymns and other ritual texts refers to a relative unity, a kind of momentaneous primeval status and thus a potential for coming into being, which any god may assume. - And, as Hornung almost points out, the proper place for a god to do so is ritual! It is in ritual that everything assumes primeval status, and it is in ritual that a new beginning is made by reducing the god to the fertile unity of potential being.

It is an astonishing, but I think undeniable, fact that participants in almost a hundred years of discussion about "monotheist tendencies" in ancient Egyptian religion simply failed to acknowledge that their source material was ritual texts, in which they should not expect to find catechetic statements on the nature of God. Uncritical compilation around the theme of the one or sole god gave rise to competing historical constructions in a field where closer inspection of the ritual context in which it is found would have yielded a consistent analysis and revealed a considerable historical continuity.

The debate on ancient Egyptian kingship was perhaps shorter, but in those hectic years when it was nourished by the international interest in sacral kingship, most intense in the $1950 \mathrm{~s}$ and $60 \mathrm{~s}$, it exhibited a similar pattern. Among egyptologists the debate took a peculiar turn because, as brought out by Henri Frankfort (1948b), many Egyptian texts explicitly call the king a god. Since also the human nature of the king is represented in the source material, speculations about the two natures of the Egyptian king were almost bound to haunt egyptology. Hans Goedicke (1960) found them in the Old Kingdom (2640-2160 B.C.) use of the two terms njswt and $h m$, the first denoting 'das Herrschertum schlechthin', the second its 
temporal human bearer. In the same year G. Posener (1960) published an intelligent critique of the way the evidence had been uncritically compiled around the idea of the divine king. Notably by contrasting the image of the king in royal inscriptions and in free narratives he demonstrated that the human nature of the king was clearly perceived by his subjects. Once more, a critical assessment of the textual basis for the fluctuations of a concept uncovers distinct levels. - In an otherwise valuable essay S. Morenz (1964) suggested that the divine king be taken as the starting point in a long historical process in which the king gradually loses his divine nature and the divine assumes a more and more transcendent character. Strengthened by the actual weakening of kingship at the end of the Old Kingdom the process goes on and on as a 'dissonantic accord' throughout the history of Egyptian religion. Much can be said in favour of Morenz's tracing of the process in the better known periods, but it is difficult to escape the impression that the theory of divine kingship now shares the fate of fetishism, totemism, and dynamism: transposition into an all-embracing prehistory. As we have seen before, a huge diachronical construction now accounts for synchronous discrepancies.

It was with clarifying effects, therefore, that W. Barta (1975) introduced the distinction between ritual and universal belief: On the basis of Early Dynastic and Old Kingdom evidence, he at last established that whenever the king is represented as divine, this refers to a ritual status. The king is a god in his ritual roles, mythological or non-mythological, and no preritual divinity can be claimed for any king. Intricate problems like the king's two natures or the 'dissonantic accord' arise when all statements about the king are taken as expressions of universal belief. United at this single level, they defy any consistent description; but on the ritual level distinguished by Barta we may, undisturbed by bourgeois common sense, perceive the divinity of the king.

\section{A Definition of Ritual}

In four well documented cases we have seen that the investigation of a theme may sometimes demand an awareness of certain distinct levels of analysis. If only one, all-embracing level, vaguely defined as 'religion', 'world view', or the like, is operated, it is often difficult to arrive at a consistent analysis, and diachronical distortion of contemporary source material has more than once been the sole expedient in the face of discrepancies. Throughout our four cases we have found that considerable 
clarification is obtained by isolating the ritual level. We have not, however, given any clue to its identification. To account for its relations with other levels, such as those where myths, religious ideas, attitudes, etc. belong, would take us close to a complete system or hierarchy of levels - and far beyond the more modest aim of this paper. But at least partial results could be obtained through a definition of ritual that meets the demands of our four cases. If themes known from myths, religious ideas, etc. assume a different character at the level of ritual, our definition of ritual will have to provide a general framework to account for such differences.

A definition of ritual is a task that might take volumes, and the following discussion should not be taken as anything like an account of current opinions. A fairly recent definition of ritual, which I believe covers much of the modern consensus, is, however, the one given by Zuesse (1987) in the Encyclopedia of Religion:

For our purposes, we shall understand as "ritual" those conscious and voluntary, repetitious and stylized symbolic bodily actions that are centered on cosmic structures and/or sacred presences. (Verbal behavior such as chant, song, and prayer are of course included in the category of bodily actions). (Zuesse 1987: 405)

Definitions, like confessions, usually bear the marks of past heresies. 'Conscious and voluntary' serves to distinguish ritual from neurotic compulsions, from which it was once fashionable to derive it. 'Repetitious' points to a prominent feature of ritual: most rituals are repeated, and many claim to be repetitions of mythical prototypes. On the other hand, logical problems may arise if repetition of a certain action is taken as a necessary criterion that it is such an action. Eating and drinking are also 'repetitious' actions, but the repetition which is essential for the sustenance of life is not intrinsic to the notion of eating or drinking. The word 'stylized' excellently characterizes a lot of ritual procedures, even though considerable variation can be shown in this matter. The term 'symbolic' is likewise indisputably relevant, even in spite of the rich varieties of meanings attached to it.

'Bodily', however, excludes meditations that follow a prescribed course and also those who pray silently, unless we presume that their larynx vibrates. Students of Buddhist practices should certainly object to having ritual confined to bodily action, and even in Vedic ritual, the cosmological and mythological knowledge conveyed by the Brahmanas is considered essential to the efficacy of the rites, although it is not displayed in bodily action. 
Stripping the definition of those adjectives that are unnecessary or entail logical difficulties, and those which, from a comparative point of view, draw very artificial lines of distinction, we are left with 'symbolic actions', and the additional qualification that they have to be 'centered on cosmic structures and/or sacred presences'. - 'Centered on' betrays very little about the manner in which cosmic structures and sacred presences are central to ritual, but there is no doubt that most often they are. It seems, however, that there are also actions so far counted as rituals to which these characteristics are not easily applied. Where are the cosmic structures and/or sacred presences of protestant marriage - or, for that matter, the turtle dance of the Andaman islanders (Brown 1922: $91 \mathrm{ff}$.)? There is a striking difference between the accurately elaborated formal characteristics of the first part of the definition and the vagueness of the second part - the one intended to account for the religious nature of ritual.

Yet Zuesse's definition may be useful as a collection of adjectives and other characteristics that may often be applied to ritual. The frustration it leaves and the doubts that it raises in the mind of the intelligent reader are mainly due to the fact that it does not indicate any interrelation or interaction between the seven characteristics gathered round the word 'actions'. In order to be useful a definition must, I believe, imply some sort of relation between the characteristics it joins together. In the case of ritual, this could be obtained if the formal characteristics were related to the purpose ${ }^{1}$ of ritual. Those who deal with patent specifications know how important it is to state the purpose of an invention; the inventor of an umbrella with a hole for a flag used in welcoming homecomers to our rainy country is not entitled to royalties from everybody with a leaky umbrella.

To generalize about the purpose of ritual is perhaps no easy task. It ranges from the renewal of the universe to the curing of obstipation, and sometimes no purpose is apparent at all. It is, however, safe to say that all rituals aim somehow at governing the course of events; they are intended to work on whatever object they have, to change it or to maintain it. A ritual is designed and performed on the assumption that once it is accomplished, the world is not quite what it would have been without the ritual. - Edmund Leach (1976: 9) ${ }^{2}$ distinguishes three aspects of human behaviour:

\footnotetext{
1 My emphasis on 'purpose' coincides with, and owes a certain debt to, some of the importants considerations on ritual as "instrument and purpose" by C. G. Diehl 1956: 13-35.

2 The three aspects are not mutually exclusive "types"; a technical action may also involve biological activity and at the same time be 'expressive'.
} 
(1) "natural biological activities of the human body",

(2) "technical actions, which serve to alter the physical state of the world out there", and

(3) "expressive actions, which either simply say something of the world as it is, or else purport to alter it by metaphysical means".

The category of expressive actions is thus divided into two: those that describe the world, and those that work on it, i.e. rituals. The latter subcategory was taken by J. G. Frazer, in his theory of magic, as due to a confusion of aspects (2) and (3) (Leach 1976: 29), but Leach insists on it as a self-contained aspect of the broad field of 'expressive actions' - or, to use a key word from the title of his book: communication.

If ritual is communication, it is certainly a peculiar kind of communication. For what usually constitutes communication is the interaction of a sender, a message, and a receiver; and since ritual "purports to alter the world by metaphysical means", it is not in need of a receiver. There may, of course, be a lot of ordinary communication in a ritual performance; a ritual may communicate to its participants or onlookers a survey of social structures, an official recognition of a change of status, a sense of the divine, or just a feeling that things will be all right now. But none of these, and numberless other, cases of ordinary communication are prerogatives of ritual, just as the technical actions and the natural biological activities usually involved are not constituents of the notion of ritual.

But could not ritual be described as ordinary communication with extraordinary receivers? Often gods, demons, animals, plants, and even lifeless substances are addressed in rituals. Is it not the aim of ritual somehow to motivate such more or less intelligent agencies in favour of the desired outcome? 'These receivers are, I believe, best considered part of the ritual - unless we want to make a radical distinction between prayer and drama, between persons speaking to an invisible god and persons enacting some aspect of the interaction of gods and men. A ritual will often represent communication with some receiver; but the ritual has no additional receiver.

Ritual is communication only in the sense that it represents something; it refers, signifies and makes sense; but it is not designed to inform or persuade any extra-ritual agency. It is designed to work, to act directly on whatever object it has. In this respect it is akin to what Leach called 'technical actions', but also different from this category, since it acts by means of exactly those features that make it akin to communication: by representing. - We shall accordingly define ritual as representative acts 
designed to change or maintain their object, thus distinguishing ritual from all other kinds of communication and from all other kinds of action. This definition is independent of any attempt to define religion, and some of my colleagues will no doubt find it too broad and inclusive. All that is needed to exclude a residual group of non-religious rituals is, however, to add your favourite definition of religion.

Although our definition focuses on ritual efficacy, it is also independent of local variations of the belief in ritual efficacy; all it requires is that the action is formally designed to work. Thus postulating a certain relation between the form and the aim of ritual, our definition invites studies of the way representations are put to work in ritual. - But it also meets the demands of our four cases by providing a framework to account for the way themes and motifs are transformed at the level of ritual: They are represented as means towards the end of the ritual. Kongchen and Nazongnyo are represented as potential causes of illness in a ritual process that aims at annihilating illness through a ritually produced and ritually controlled crisis. In an analogous way, the idea of ritual as a dynamic process of representations towards a certain aim accounts for the tension found in Maasai hymns and prayers, where the god is on the one hand identified with elements of nature and, on the other hand assumes anthropomorphic features in the supplicating passages. What is represented is ritual dynamics, not theological propositions.

In ancient Egyptian religion, ritual dynamics notably takes the form of re-enactments of mythical exemplars. Often this involves a ritual point zero which is at the same time a liminal crisis in the sense of Victor Turner (e.g. 1974: 93-111) and a mythical chaos, containing the possibility of creation as well as the risk of perdition. It is at this point zero, in the undifferentiated primeval non-being of the ritual, that the god is represented as the mythical creator: alone, with none beside him. Like Maasai hymns and prayers, Egyptian ritual texts sometimes exhibit a tension between representations of the divine that would, at the level of catechism, be mutually exclusive. Often it is a tension between the one god and the god who is manifest in multiple forms; in a single sentence the god may be called "the one who makes himself into millions". The image of god is not a static one, but one that takes form in the creative dynamics of ritual.

The ritual divinity of the Egyptian king is understandable along similar and even more general lines. Ritual persons are very often identified with gods in order to serve the purpose of a ritual. It is from the mythical and the divine standpoint worked up by ritual that an effect on the world can 
be achieved; and by being ritually his mythical and divine exemplar, the king ensures that the primeval pattern is reproduced to renew and uphold the world. Accordingly, the king may even outside the ritual context be called a god, referring to his ritual role. This is, however, not a religious idea or an ideology that prevents his subjects from being fully aware of his human nature.

If our definition of ritual has thus indicated the conditions for the transformations of themes and motifs at the ritual level, we have at the same time defined the field of ritualistics - not as a methodological monopoly, but as a distinct level of analysis. Ritualistics is the study of ritual dynamics, i.e. of the way representations are put to work in ritual. Accordingly, it is also a study of form and meaning in ritual, which we must now consider more closely.

\section{Meaning and Form in Ritual}

Frits Staal (1989) found in previous studies of ritual a vain obsession with meaning, and what he offers is a study of ritual as rule-governed activity without meaning, a study of pure form more akin to the study of music than to linguistics. Considering form as prior to meaning, he admits, however, that ritual attracts meanings: "Rites and mantras suck up meanings that come their way like black holes suck up matter" (Staal 1991: 233). Even in linguistics, it is possible to isolate a level that in itself has no meaning; in fact, this is what Saussurian linguistics does in order to arrive at the idea of the arbitrariness of the linguistic sign. The meanings attached to sounds and combinations of sounds are also acquired meanings, which convention has taught people to use and understand. And who knows for how many years our remote ancestors went on uttering nonsensical - but perhaps "rule-governed" - sequences of sounds before they hit upon the ill-fated expedient of attaching meaning to them? But one cannot therefore say that sounds or even rule-governed sequences of sounds are more essential to language than meaning. We have also learnt from the early history of our discipline, I hope, that analytical levels should not be projected into history or prehistory. It seems that Frits Staal has discovered a nonsensical level of ritual so fascinating that he does not hesitate to dismiss all the rest as accessory. The over-abundance of meaning with which it is almost everywhere invested may then, very much 
in the spirit of Fr. Creutzer, be seen as the product of inert sacerdotalism, later followed up by ambitious students of religion.

The discipline of ritualistics here proposed deals also with meaning in rituals. There is, however, something to the case for meaninglessness advocated by Frits Staal. The meaning found in ritual is not straightforwardly the meaning of ritual, for as we have already seen, ritual is not a message. The logic and meaning of the representations displayed in ritual are not there to inform or persuade, but to work. This is perhaps best illustrated by elaborate studies of the processual form of rituals such as those carried out by Victor Turner $(1970 ; 1974)$; but for the sake of brevity, let us try to make our point on the basis of a single ritual formula:

Like those European magical formulae that were in common use till the beginning of the present century, Egyptian formulae regularly subject their case to cosmological control by citing a mythical exemplar of the pertinent case, thus, as it were, reducing it to its cosmological significance. ${ }^{3}$ This is, however, not the only way of exerting ritual and cosmological control; it may also be done in a negative mode, by interpreting the danger or the disease to be handled as cosmologically impossible or at least unimportant. In a collection of spells for mother and child from about $1700 \mathrm{BC}$ the following formula is addressed to some illness in a child, ritually personified as a female demon:

... You who spend your time making mud-bricks for your father Osiris! You who say against your father Osiris: 'May he live from $d 3 j s$ and honey!' Run out, you asiatic woman who come from the desert, you negro woman who come from the wilderness! Are you a handmaid? - come in vomiting! Are you a noble woman? - come in his urine, come in the snot of his nose, come in the sweat of his body! - My hands are on this child - The hands of Isis are on him, as she lays her hands on her son Horus. (Erman 1901: 14)

Osiris never had a daughter, and even if he had, she could hardly have been a maker of mud-bricks; it is a dirty job, not suitable for the daughter of a king. And as if this social dérangement were not sufficient demonstration of her impossibility, she is quoted for a statement of such worldoverturning absurdity that there is no longer any doubt: she does not exist! That Osiris, who as a god lives from Maat, should nourish on d $3 j s$, a vomitive, which is, as an extra refinement, mixed in honey, is not only inconceivable; it cannot conceivably be said or proposed. Bringing d3js into a temple was considered a desecration. - The disease is thus

3 For details and documentation, cf. Podeman Sørensen 1984. 
identified with an impossible mythical person, not unlike the second son of Mary in European magical formulae, a person who cannot exist at all.

Correspondingly, the disease is later called an Asiatic woman from the desert and a Negro woman from the wilderness. Geography is a cosmological discipline as well as mythology: the people who live in the desert and the wilderness, outside the cultivated Nile valley, are likewise cosmological outsiders and somehow less real than Egyptians. In this way the formula cuts off the disease, mythologically and cosmologically, but it ends up in a positive identification of mother and child with Isis and Horus.

The formula not only illustrates how danger and disease may be interpreted as something anticosmic or impossible; it also demonstrates that several different mythological and cosmological interpretations may occur side by side in one and the same formula: The vicious daughter of Osiris, an Asiatic woman, and a Negro woman are parallel designations of the disease, in as far as they serve to cut it off from cosmology; but taken literally, they are mutually exclusive. And the positive mythological identification is in the end still another approach to the cosmological reduction of the actual situation. ${ }^{4}$

There is plenty of meaning in this formula, even more than could be united into a coherent message. What unites the mutually exclusive statements is the ritual, in which they are means towards curing the child, and it is in this context that they make sense. In ordinary communication, meaning is the end product; in ritual, meaning is a means towards whatever end or purport it has. - We may also observe that the ritual is made up of meaning or meanings; it is through their meaning that the statements are considered efficacious. Meaning is to ritual very much what sound is to language.

Our single small scale specimen may also serve to illustrate the processual form of ritual. The three approaches to the ilness as a female

4 We are thus facing a specimen of what Henri Frankfort (1948a: 4) called 'multiplicity of approaches'. Frankfort's idea of 'ancient thought' or 'mythopoeic thought' as "admitting the validity of several avenues of approach at one and the same time" (1948b: 41) is, I believe, mainly based on Egyptian ritual texts. In this literature it is not uncommon to find a series of parallel statements, each representing a definite approach. Such a series of concrete statements may be considered a paradigm expressing an abstract relation: the three identifications of the disease are mutually exclusive, but admitted side by side they express very well its anti-cosmic nature. - Although it has been of great value in the study of ancient Egyptian religion, Frankfort's idea of 'ancient thought' is another specimen of the leap from the level of ritual to a level of religious thought, similar to what we have pointed out above. 
demon make up a redundant sequence, in as far as they all identify the illness as "non-being". Considered as a sequence or process, they call the illness down, first in mythological terms, then in terms of (geographical) cosmology, to point zero, where it may be commanded: come out! It is at this crucial moment that recourse is had to the further ritual control that is contained in the mythological identification of mother and child with Isis and Horus.

A more convincing case could, perhaps, be made by an elaborate analysis of a more comprehensive ritual sequence, but our tiny specimen at least illustrates our point: In ritual, meaning and form are determined by the ritual aim they serve; they are indeed essential to ritual but not its end product. This means that the study of meaning and form as ritual dynamics has to be different from other studies of cultural meanings and forms. The form is not there to convey the meaning, but rather the meanings are there to fit the form, which in turn must fit the purpose.

It is with a view to the further exploration of the way meaning and form are put to work in ritual, and the way ritual determines and conditions the form of representations, that I suggest ritualistics as a new discipline. University courses could already be held on the basis of quite a number of relevant studies of ritual. The new discipline could replace part of the phenomenology of religion and provide a basis for more precise descriptions and studies of a host of interesting themes that somehow involve ritual or ritual texts.

\section{References Cited}

\section{Barta, Winfried}

1975 Untersuchungen zur Göttlichkeit des regierenden Königs. München: Deutscher Kunstverlag. (Münchner ägyptologische Studien, 32)

Brown, A. R.

1922 The Andaman Islanders. Cambridge: Cambridge University Press.

Diehl, C. G.

1956 Instrument and Purpose. Studies on Rites and Rituals in South India. Lund: C. W. K. Gleerup.

Erman, Ad.

1901 Zaubersprüche für Mutter und Kind. Berlin: Verlag der königl. Akademie der Wissenschaften. (Abh. d. königl. preuss. Akad. d. Wiss.)

Frankfort, Henri

1948a Ancient Egyptian Religion. New York: Columbia University Press.

1948b Kingship and the Gods. Chicago: University of Chicago Press. 


\section{Goedicke, Hans}

1960 Die Stellung des Königs im alten Reich. Wiesbaden: Otto Harrassowitz. (Ägyptologische Abhandlungen, 2)

\section{Hornung, Erik}

1971 Der Eine und die Vielen. Darmstadt: Wissenschaftliche Buchgesellschaft.

Lawson, E. T, and R. N. McCauley

1990 Rethinking Religion. Cambridge: Cambridge University Press.

Leach, Edmund

1976 Culture and Communication. Cambridge: Cambridge University Press.

Morenz, Siegfrid

1960 Ägyptische Religion. Stuttgart: W. Kohlhammer. (Religionen der Menschheit, 8)

1964 Die Heraufkunft des tranzendenten Gottes in ägypten. Berlin: Akademie-Verlag. (Sitzungsber. d. Sächsischen Ak. d. Wiss. zu Leipzig, Phil.-hist. KI. 109/2)

Olsson, Tord

1975-1982 Religious Documents of the Maasai. 3. vols. Lund [mimeographed]

1983 Gudsbild, talsituation och litterär genre. Föreningen Lärare i Religionskunskap. Arsbok: 16, 91-109.

Podeman Sørensen, J.

1984 The Argument in Ancient Egyptian Magical Formulae. Acta Orientalia 45: 5-19.

Posener, Georges

1960 De la divinité du pharaon. Paris: Imprimerie Nationale. Cahiers de la Société Asiatique, 15)

Siiger, Halfdan

1967 The Lepchas. Vols. 1-2. Copenhagen. (Nationalmuseets skrifter, etnografisk række, 11/1-2)

1978 Myte og kult. In: Mogens Mugge Hansen (ed.), Venner af Prins Peter; pp. 125-131. København: Finansbanken.

Staal, Frits

1989 Rules Without Meaning: Ritual, Mantras and the Human Sciences. New York.

1991 Within Ritual, about Ritual and Beyond. Religion 21: 227-234.

Turner, Victor W.

1970 Betwixt and Between. In: Victor W. Turner, The Forest of Symbols; pp. 93111. Ithaca: Cornell University Press.

1974 The Ritual Process. Harmondsworth: Penguin Books.

Zuesse, Evan M.

1987 Ritual. In: Mircea Eliade (ed.), Encyclopedia of Religion; vol. 12: 405-422. New York: Macmillan. 